\title{
Coaching for development of leaders' awareness of integrity: An evidence-based approach
}

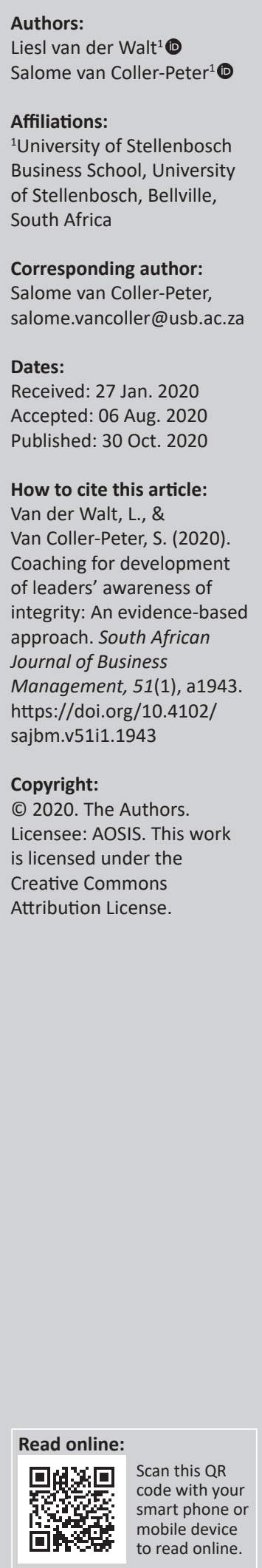

Purpose: There is a need for leading with integrity to contribute to sustainable effectiveness and performance in the organisational context. The purpose of this research was to provide insight into the elements that could facilitate the development of leaders' awareness of integrity to support positive leader outcomes.

Design/methodology/approach: Interpretative phenomenological analysis (IPA) was the research design, and purposive, convenience sampling was utilised to select six leaders. Data were collected through semi-structured interviews with these leaders and reflective notes of the researcher as coach to explore leaders' experience of the contribution of coaching to the development of awareness of integrity.

Findings/results: Based on the experiences of these leaders, the findings suggest that even a small number of coaching sessions using a strengths-based approach contributed towards an increase in awareness of the importance of integrity. Positive leader outcomes were also identified. The study supports the use of a strengths-based approach to coaching, such as a solution-focussed cognitive-behavioural (SF-CB) approach, whilst coaching leaders.

Practical implications: The findings have implications for organisations and coaches. The findings confirm the selection of coaching as a suitable intervention to develop awareness of integrity and achieve positive leader outcomes. Findings provide evidence to guide human resources professionals whilst deciding on an appropriate intervention for leader development. In addition, coaches could base their selection of an approach on the evidence supporting the use of an SF-CB coaching approach in the context of developing leaders' awareness of the importance of integrity.

Originality/value: The findings highlight the efficacy of using a strengths-based approach specifically an SF-CB approach - to increase leaders' awareness of integrity and drive positive leader outcomes.

Keywords: business coaching; character; integrity; leader awareness; leader development.

\section{Introduction}

Character as a feature of leadership is becoming more relevant as organisational complexity increases. Social media and newspapers regularly report instances of lapses of integrity, dishonesty and a general lack of character (Newstead, Dawkins, Macklin, \& Martin, 2019). Examples of leadership scandals internationally include the actions of the Chief Executive Officers (CEOs) of Enron and Arthur Anderson (Mclaughlin, 2013). Locally, Steinhoff CEO Markus Jooste has been alleged to misrepresent and misreport financial information (Naudé, Hamilton, Ungerer, Malan, \& De Klerk, 2018). It is possible that many employees today have similar workplace experiences of leadership lacking in character.

Well-developed leader character could contribute to effective leadership and sustainable performance in organisations. This notion of the importance of character is widely held in leadership research (Palanski \& Yammarino, 2011; Sosik, Gentry, \& Chun, 2012). Crossan et al. (2017) confirmed that leader character should be considered as important as leader competencies in organisations. This focus on character can be achieved by embedding leader character in systems and processes such as recruitment and selection, performance management and leadership development (Crossan et al., 2017; Seijts, Crossan, \& Carleton, 2017).

Leaders deemed to possess character have much in common. Fairness, justice, care and integrity are all given as examples of leader character (Newstead et al., 2019). Whilst research proposes various definitions of character, the core seems to centre on integrity (Conger \& Hollenbeck, 2010; 
Kaiser \& Hogan, 2010; Palanski \& Yamarino, 2011). This notion of integrity as core to character is supported by Sosik et al. (2012) who hold integrity to be a key dimension of character and a contributor to executive performance and effectiveness. It has been argued that the absence of integrity could result in leadership becoming coercive (Newstead et al., 2019). Research by Kaiser and Hogan (2010) estimated a range of $10 \%$ to $20 \%$ of thousands of leaders assessed to have low integrity. It is for these reasons that integrity has been selected as the focus of this study.

The development of leaders' awareness of integrity can be achieved through various means. This view is supported by Kegan (1982) who stated that individuals develop progressively more complex understandings of their environment through their accumulated experiences. Leaders can enhance their awareness of integrity through deliberated interventions such as training and mentoring and through relationships and challenging experiences (McKenna \& Campbell, 2011; Peterson \& Seligman, 2004; Seijts, Gandz, Crossan, \& Reno, 2015; Sosik et al., 2012). In addition, coaching of leaders is considered one of many appropriate interventions for leader development aimed at improving leader behaviours and performance (Anthony, 2017; Grant, 2017a). According to Cox, Bachkirova and Clutterbuck (2014), coaching is fast becoming a preferred activity serving the learning and development aims of organisations.

Development of leaders' awareness of integrity as a dimension of character is neither well defined nor regularly discussed (Seijts et al., 2015). If leader integrity is important for an effective leadership and sustainable performance, then it is imperative that organisations provide appropriate support to leaders to develop their awareness of integrity. It is not well known what key elements are best suited for the development of awareness of integrity in leaders. With this in mind, the research question that guided this study was: What are key elements to develop the awareness of integrity in leaders resulting in positive leader outcomes? Insight into these elements could provide guidelines for facilitating the development of leaders' awareness of integrity in organisations to support positive leader outcomes.

This article provides theoretical perspectives related to leader integrity and business coaching. This is followed by a discussion on interpretative phenomenological analysis (IPA) as the methodology employed to gather data from six leaders at director level. The article is concluded with a discussion of the findings and the provision of guidelines to facilitate the development of leaders' awareness of integrity.

\section{Literature review}

In this review, a definition of leader integrity is proposed, followed by current views in literature on the development of leaders' awareness of integrity. Business coaching as intervention to develop leaders' awareness of integrity includes coaching with a solution-focussed cognitivebehavioural (SF-CB) model.

The main theoretical perspectives informing this research draws from both the leadership and coaching fields, as illustrated in Figure 1:

Numerous references in the literature refer to integrity as character virtue. Consider Palanski and Yammarino's (2007) leadership literature review in which they found 20 sources citing integrity to imply moral virtue. Integrity is a character strength signalling the virtue of courage (Peterson \& Seligman, 2004). If good character is made of a set of virtues there is every reason to expect that the virtue of integrity would be tied in with related virtues such as fairness, honesty, authenticity and compassion (Macintyre, 2007). It is therefore understood that integrity is a necessary but not a stand-alone part of character (Palanski \& Yammarino, 2007).

Virtues can be classified as either adjunctive or substantive in nature. Adjunctive virtues are neither good nor bad in a moral context but are still necessary for desirable behaviour. Integrity should be categorised as an adjunctive virtue. Examples include integrity, courage and steadfastness. In comparison, substantive virtues are themselves morally good and include honesty and fairness (Palanski \& Yammarino, 2007, 2011). Put differently, to demonstrate honesty or fairness is to act inherently in a morally principled way, whereas acting with integrity is associated with alignment between words and deeds (Gentry et al., 2013). Integrity as adjunctive virtue is considered here as an issue of personal identity and not necessarily as a moral virtue (Becker, 2009).

Leader integrity can be defined as acting in accordance with stated values, following through on promises, and using ethical considerations to guide decisions and action. This fits well with the conceptualisations of Palanski and Yammarino and Six, De Bakker and Huberts, as well as with the view of Peterson and Seligman that integrity is at the crossing between honesty and authenticity (Palanski \& Yammarino, 2011; Peterson \& Seligman, 2004; Six, De Bakker, \& Huberts, 2007). The operationalised version would include behaving consistently with ethical standards, even in difficult situations; others see it as behaving in a way that is consistent with their personal values and beliefs (Crossan et al., 2017; Seijts et al., 2015; Seijts \& Gandz, 2018). Integrity is also

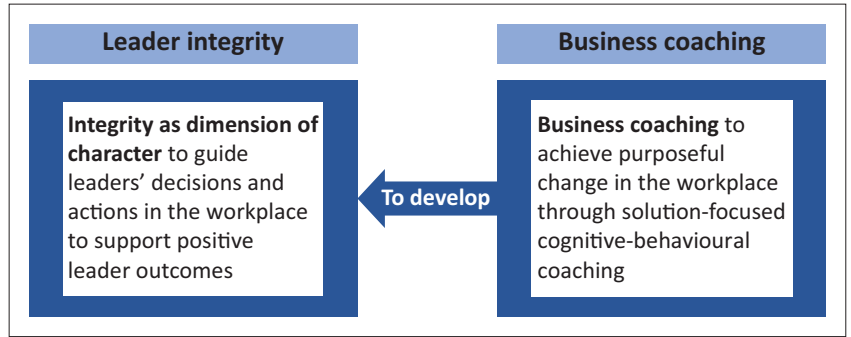

FIGURE 1: Theoretical perspectives underpinning this research. 
conceptualised as word-act congruence and a moral perspective of what is right or wrong (Six et al., 2007). Organisational and leadership literature has been more flexible about the meaning of integrity and seems to have settled on a non-moral definition (Bauman, 2013).

The impact of leaders with issues of integrity is worthy of consideration. Research on leadership theories supports the claim that integrity is a prerequisite for leadership. The findings indicate that leaders deemed to have high integrity are more likely to win the trust of followers (Kaiser \& Hogan, 2010). Research by Grahek, Thompson and Toliver (2010) found leaders' personal integrity to be critically important as reported by both leaders and followers. There is a clear need for leaders to develop and practise leading with a virtue such as integrity (Newstead et al., 2019). The development of integrity in leaders starts with awareness.

Awareness of integrity can be developed through various means. Leadership research has shown that integrity is a function of lived experiences as well as cultural and environmental influences, suggesting that it can be developed (Hannah \& Avolio, 2011; Peterson \& Seligman, 2004). It is not suggested that an awareness of the importance of integrity will lead to only virtuous decision-making. Even leaders with strong and well-developed character could exhibit unethical behaviours (Crossan et al., 2017). It is, however, possible that decisions will be better informed.

Leader development is concerned with interventions to develop the leader's character, skills and competencies. Leadership is contextual and it is important to consider the appropriate intervention. What works to move one leader to action in a specific context might not work to move another leader to action in a different context (Newstead et al., 2019). The ultimate aim of learning, training and development (including coaching) is to maximise human potential and increase performance (Cox et al., 2014; Jones, Woods, \& Guillaume, 2016). Training and development as interventions could be measured through cognitive, skillbased and affective outcomes (Jones et al., 2016). This could be achieved by capitalising on strengths and eliminating shortcomings (Riggio, 2008). Research found evidence that coaching could deliver on cognitive, skill-based and effective outcomes. It was suggested that potential issues in training transfer can use the support of coaching to achieve a sustainable change (Jones et al., 2016). Grant (2017b) believed that organisations and leaders are looking towards coaching to deal with increasing complexity and uncertainty. Specific to integrity as dimension of character, research suggests a positive influence of business coaching on character development in leaders (Ely et al., 2010; Grant, Green, \& Rynsaardt, 2010; MacKie, 2014). Finally, the supportive relationship between coach and client, the setting of personally valued individual goals and coach support during times of setback all indicate coaching as appropriate intervention in addressing development of awareness (Grant, 2014).
Increasing awareness of the importance of certain behaviours through coaching can lead to immediate change (Welch, Grossaint, Reid, \& Walker, 2014). This view is supported by Avolio and Gardner (2005) who suggested that reflection increases awareness of leaders' personal values, beliefs, feelings and actions in the organisational context. Coaching as a selected intervention should therefore include specific factors contributing to permanent learning. A literature review by Rekalde, Landeta and Albizu (2015) included various success factors deemed important in coaching. Key factors were identified across five sections: coach, client, coaching relationship, process and organisational context. The findings support results from other studies in identifying a common factor required for sustainable change, namely the coaching relationship (De Haan, Culpin, \& Curd, 2011; Grant, 2017a).

Leaders who have received coaching are more likely to model and provide individualised consideration to their supporters. This is achieved through developing the leaders' ability to build trust, act with principle and integrity and inspire and develop others. Therefore, business coaching is deemed effective in developing character as part of leadership development (MacKie, 2014).

There are many definitions of business coaching. Business coaching is concerned with the development of managerial leaders and teams in a way that is sustainable, measurable and effective (Stout-Rostron, 2012). Grover and Furnham (2016) explained that business coaching is a broad term referring to any process whereby an individual receives coaching to improve performance within an organisation. Cox et al. (2014) defined coaching as a development process involving a structured process and tools to promote sustainable change. In business coaching the role of the organisation, not only as a sponsor but also as a partner, is significantly different from the focus on the individual needs of the client in counselling (Cox et al., 2014; Kahn, 2011). The following definition of business coaching is offered for the purpose of this study. It is typically about assisting clients in improving their self-management skills to achieve purposeful positive change in the workplace and is therefore considered to be goal-focussed (Grant, 2012; Passmore, 2007). The role of a coach is to foster change by supporting the client through a self-regulatory sequence with the aim of stimulating sustained well-being and functioning (Grant, 2003, 2017a). In short, coaching is essentially about fostering self-directed changes in clients to make them feel and function better. According to Cox et al. (2014), there are many evidence-based approaches to coaching, as set out in Table 1.

A study by De Haan et al. (2011) found that the technique or approach used by the coach was less important than the relationship with and qualities of the coach. Arguably, all of the above approaches could support individual learning experiences (Cox et al., 2014). The use of a solution-focussed 
TABLE 1: An overview of a number of evidence-based approaches to coaching.

\begin{tabular}{ll}
\hline Approach & Premise of approach \\
\hline Psychodynamic approach & $\begin{array}{l}\text { Unconscious motives rooted in past experiences } \\
\text { affect current behaviours and feelings }\end{array}$ \\
$\begin{array}{l}\text { Cognitive-behavioural } \\
\text { coaching }\end{array}$ & $\begin{array}{l}\text { Aims to provide insight regarding unhelpful cognitions } \\
\text { and supports more effective thinking resulting in new } \\
\text { behaviours }\end{array}$ \\
Solution-focussed coaching & $\begin{array}{l}\text { Focussed on constructing a pathway to goal } \\
\text { attainment utilising existing strengths and working } \\
\text { from the present }\end{array}$ \\
Gestalt approach & $\begin{array}{l}\text { Focussed on clients' in-the-moment awareness in } \\
\text { relation to experiences, the external world and blocks } \\
\text { to awareness }\end{array}$ \\
$\begin{array}{l}\text { Neuro-linguistic } \\
\text { programming (NLP) } \\
\text { approach }\end{array}$ & $\begin{array}{l}\text { Aims to identify patterns of how clients construct } \\
\text { their realities to control their inner experiences in a } \\
\text { given specific context }\end{array}$ \\
Person-centred coaching & $\begin{array}{l}\text { Based on the assumption that clients will develop in } \\
\text { constructive ways given the appropriate conditions } \\
\text { being present }\end{array}$ \\
Narrative coaching & $\begin{array}{l}\text { Forming new connections between stories, identities } \\
\text { and behaviours as narrated by the client }\end{array}$ \\
\hline
\end{tabular}

approach in organisations is supported by empirical evidence (Grant, 2003; Theeboom, Beersma, \& Van Vianen, 2014). A solution-focussed approach was therefore considered an appropriate process to achieve change.

Various theories are linked to solution-focussed coaching. A solution-focussed approach is aimed at facilitating purposeful positive change (Grant, 2012), and there is an overlap with positive psychology, with regard to positive experience, positive personality and positive communities (Seligman \& Csikszentmihalyi, 2000). One of the theorists of positive psychology, Barbara Fredrickson, proposed that positive emotions broaden our thought-action ranges and build longterm personal resources. Her broaden-and-build theory holds that positive emotions generally expand the range of thoughts and actions (Fredrickson, 2001). The link is that solution-focussed techniques concentre directly on positive emotions. In line with positive psychology, a solutionfocussed approach seems to be distinctively placed to support the building of both positive emotions and extended thought-action ranges (Glass, 2009). Both positive psychology and solution-focussed coaching are ultimately concerned with helping clients to flourish and have a better future (Bannink \& Jackson, 2011).

Self-determination theory is relevant to solution-focussed coaching as both have an autonomy-supportive facilitation approach. The presuppositions, principles and techniques of a solution-focussed approach have the effect of supporting the perception of autonomy, competence and relatedness of clients which, according to self-determination theory, are keys to support self-determination (Visser, 2009). Selfdetermination theory is a psychological theory of human behaviour and motivation, which has been empirically tested and applied in many areas including work (Ryan \& Deci, 2000).

Solution-focussed coaching is also a constructivist, humanistic approach that concentrates on the strengths of the client (Grant, 2003). A coaching's focus on the development of personal strengths and goal attainment rather than problem analysis is ensured by incorporating a solution-focussed perspective into a cognitive-behavioural framework (Grant et al., 2010). Cognitive-behavioural approaches to coaching recognise the interaction between one's behaviour, thoughts, feelings and the environment and that goal attainment is best facilitated by understanding the relationship between these four domains (Grant, 2003). According to Grant (2017a), initial coaching conversations focus on identifying personally meaningful goals to increase commitment to the goal and should precede the solutionfocussed aspect of coaching. Such intense cognitive processing facilitates thinking that supports the formulation of options and action plans (Grant, 2017a).

Continued pressure on individuals to perform is associated with increased levels of stress-related fatigue and even burnout (Grant, 2017a). Research has shown that the SF-CB coaching model is both meaningful and relevant in this context (Grant, 2017a). Improved performance and wellbeing are only possible if sustainable change in behaviour takes place. Kolb's experiential learning cycle supports transforming experience into learning (Kolb, 1984). A solution-focussed approach is associated with increased resilience in leaders, leading to an increased probability of maintaining self-regulation of the client after coaching. Various studies have provided useful evidence that solutionfocussed coaching has value in goal achievement (Grant et al., 2010).

The core of the solution-focussed approach is the premise that the coach should help the client find out what is already working for him or her and do more of it and to find out what is not working and do something different (Bannink \& Jackson, 2011; McKergow, 2016). The key underpinning presuppositions for a solution-focussed approach are a solution-focussed view as opposed to a dysfunctionality view of the problem, a future rather than a past or present orientation, a focus on disengaging from problems and actively constructing solutions, the articulation of preferred outcomes, the development of action steps towards goal attainment and acknowledging the strengths of the client (Grant, 2012).

The key principles to help the coach navigate the coaching process, according to Grant (2017a), include focussing on solutions by using reframing to change the perception of the client. They further entail focussing on what is working and encouraging the client to do more of the same: holding the client as equal to the partnership and viewing positive change on the part of the client as inevitable. A solutionfocussed approach is a first-person approach, with the coach focussing on the personal experience and imagination of the client and not on seeking to understand. It is about staying on the surface with the client and viewing each case as unique (McKergow, 2016).

This approach supports behaviour change in pursuit of a preferred outcome. Grant (2012) asserted that a positive change 
TABLE 2: A summary of potential leader outcomes as a result of coaching with a solution-focussed cognitive-behavioural model.

\begin{tabular}{|c|c|}
\hline Potential positive leader outcomes & Key support in literature \\
\hline $\begin{array}{l}\text { Character plays a role in leader } \\
\text { behaviour after feedback, resulting in } \\
\text { increased effectiveness for both leader } \\
\text { and organisation. }\end{array}$ & $\begin{array}{l}\text { Seijts et al. (2015); Sosik and Cameron } \\
\text { (2010); Sosik et al. (2012) }\end{array}$ \\
\hline $\begin{array}{l}\text { Character of leaders is foundational to } \\
\text { the quality of decision-making. }\end{array}$ & $\begin{array}{l}\text { Seijts et al. (2017); Seijts and Gandz } \\
\text { (2018) }\end{array}$ \\
\hline $\begin{array}{l}\text { Strong character drives positive leader } \\
\text { outcomes. }\end{array}$ & Sosik and Cameron (2010) \\
\hline $\begin{array}{l}\text { A leader with character is considered a } \\
\text { caring leader, resulting in followers } \\
\text { being open to leader influence attempts. }\end{array}$ & $\begin{array}{l}\text { Cohen, Panter, Turan, Morse, and Kim } \\
\text { (2014); Hannah \& Jennings (2013) }\end{array}$ \\
\hline $\begin{array}{l}\text { Integrity is associated with leadership } \\
\text { excellence. }\end{array}$ & $\begin{array}{l}\text { McKenna and Campbell (2011); Peterson } \\
\text { and Seligman (2004); Sosik et al. (2012) }\end{array}$ \\
\hline $\begin{array}{l}\text { Leaders with high integrity model the } \\
\text { behaviours they want to endorse in the } \\
\text { organisation. }\end{array}$ & Anthony (2017); Seijts et al. (2017) \\
\hline $\begin{array}{l}\text { Consistency in word-action is evident in } \\
\text { leaders with integrity. }\end{array}$ & Bass (1985); Bass and Steidlmeier (1999) \\
\hline $\begin{array}{l}\text { Leaders with integrity look beyond } \\
\text { self-interest towards attainment of team } \\
\text { goals. }\end{array}$ & $\begin{array}{l}\text { Anthony (2017); Palanski and Yammarino, } \\
\text { (2011); Wright and Quick (2011) }\end{array}$ \\
\hline
\end{tabular}

Note: Please see the full reference list of the article, Van der Walt, L., \& Van Coller-Peter, S. (2020). Coaching for development of leaders' awareness of integrity: An evidence-based approach. South African Journal of Business Management, 51(1), a1943. https://doi. org/10.4102/sajbm.v51i1.1943, for more information.

is brought about when the client uses own resilience, strengths and resources to identify ways to achieve goals. The setting of specific goals of certain levels of difficulty has been linked to increased productivity, performance and organisational profitability (Grant, 2012; Grover \& Furnham, 2016). A solutionfocussed approach, according to Grant (2003), contributes to cognitive and behavioural changes, supporting goal attainment.

Table 2 shows a summary of the ways in which leaders' outcomes may be facilitated as a result of increased awareness of the importance of integrity, through coaching with a strengths-based approach.

\section{Methodology \\ Research design}

The research design employed was IPA to gain a better understanding of leaders' experiences of the contribution of coaching to awareness of integrity. Interpretative phenomenological analysis is found within a qualitative, interpretivist research paradigm (Braun \& Clarke, 2013; Smith, 2011). Finally, this research approach is underpinned by a constructionist epistemology. It argues that there is no one truth, and a critical stance is taken regarding taken-for-granted knowledge (Braun \& Clarke, 2013). Leaders were selected consistentwithIPA, which focusses on small,fairly homogeneous samples, recommending three to six participants for a small project (Braun \& Clarke, 2013; Smith, 2011; Willig, 2008).

Purposive, convenience sampling was used to identify six leaders employed at director level and above in corporate South Africa (referred to as P1 to P6 in this article). For convenience and because of an insider perspective, the researcher selected to conduct the study in her workplace. Participants were sourced from the researcher's network at a large, listed organisation where she is employed in an executive position. Invitations were sent to all senior leaders in a cohort of 20. Specific attempts were made to define criteria for participation (Bloomberg \& Volpe, 2008). The inclusion criteria included that the leaders should not report to the researcher directly, the selection of participants should be cross-functional and the leaders should be at director level or above. Participation was on a first response basis, and the rest of the cohort was informed after six positive responses were received.

\section{Data collection}

Two methods of data collection were used, namely semistructured interviews and the reflective notes of the researcher coach. Semi-structured interviews are the preferred method of data collection for IPA (Braun \& Clarke, 2013). In addition to the interviews, the researcher as coach made reflective notes after each coaching session on both self and participants.

The participants were interviewed individually for $1 \mathrm{~h}$ by an independent fieldworker. This arrangement was decided to protect confidentiality, given the researcher's role within the organisation. Interviews were anonymised before transcribing the data. Interviews were recorded digitally and transcribed verbatim. All participants received their transcripts from the fieldworker, providing them with the opportunity to verify the accuracy of the transcripts. This process allowed for cross-checking of information, thus contributing to data validity and reliability (Babbie \& Mouton, 2012; Bloomberg \& Volpe, 2008). The process was designed to facilitate triangulation.

A basic interview guide consisting of 10 questions was used, which allowed the fieldworker to explore the leaders' awareness of integrity and their views on the contribution of coaching through a strengths-based model to develop awareness of integrity.

\section{Data analysis}

In data analysis, the first step taken was immersion in the data by reading the transcripts a number of times. A journal was kept with notes of areas and items of interest emerging from the data. An observational versus systematic approach was used during the immersion phase. In line with IPA principles, these notes were then set aside to focus on the participants' experiences (Braun \& Clarke, 2013). Brief commentary, referred to as noting in IPA, was made in ATLAS.ti to assist with data analysis.

\section{Limitations}

The fact that both initial and final interviews were conducted by an independent fieldworker could be considered a limitation. In IPA, initial immersion in the data enables the researcher to get a sense of the participants' tone and body language (Smith et al., 2009). The decision was made to protect the identity of the participants, given the researcher's role in the organisation. 


\section{Findings and discussion}

The participants' industry tenure ranged from 7 months to 16 years. Four of the participants had a minimum of 5 years' experience. The length of service could contribute to their understanding of behaviours contributing to success in the business. Three race groups were represented with a gender mix of four male and two female participants.

The findings refer to the experiences of leaders as they developed their awareness of integrity through strengthsbased coaching (specifically an SF-CB approach) and as a result, positive leader outcomes (see Figure 2 for key themes).

The participants identified three elements to support the development of awareness of integrity as a result of coaching with an SF-CB model. They also articulated three positive leader outcomes as a result of the coaching.

\section{Elements to support development of awareness}

The participants were asked to talk about the contribution of coaching to develop their awareness of the importance of integrity. Their accounts clustered around three superordinate themes: a safe space to explore, a focus on positive outcomes and time as factor.

\section{A safe space to explore}

It seemed that the partnership between a leader and researcher as coach provided a safe space to allow for meaningful conversations. The leaders could step away from their daily activities and become immersed in issues around integrity:

'It felt like I could talk safely about integrity. Trust and confidentiality were never something to worry about.' (P3)

'It was a little bit strange. Like a stop in my day.' (P1)

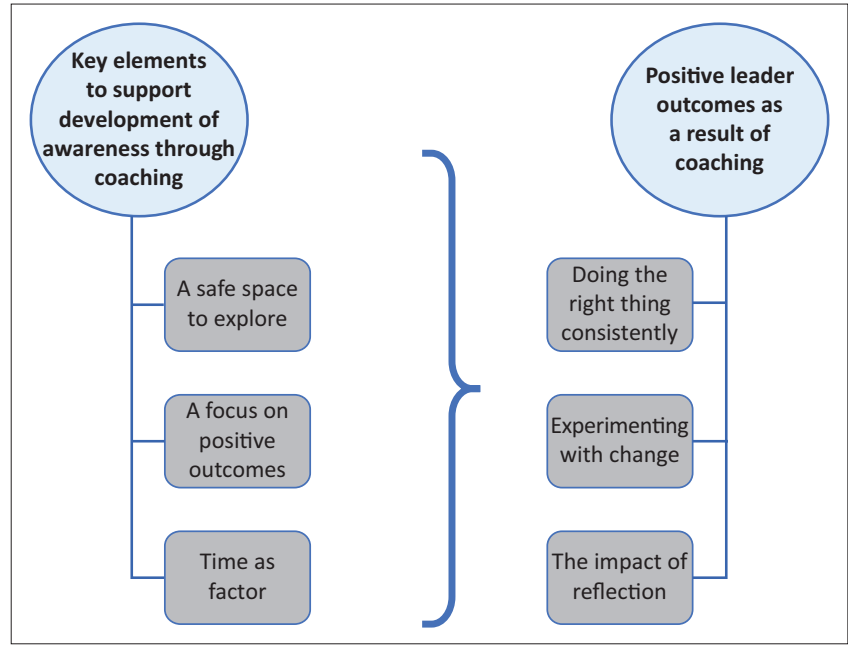

FIGURE 2: Summary of key elements to support development and positive leader outcomes.
As a researcher coach I was concerned that the participants might hold back on the topic given the existing working relationship. It seemed that the prior relationship worked as a positive aspect in this case. Trust had already been established, and little time was spent on forging a client-coach relationship. According to Passmore (2007), the relationship between coach and client is a key element of effective coaching.

Coaching enabled the leaders to think differently about integrity by looking at scenarios and perspectives not previously considered:

'But in the coaching we explored other possibilities. Like, does everyone on the team know why it is important?' (P5)

'So I know that there is more than one way to look at solving things.' (P2)

These comments support the view of Theeboom et al. (2014) that coaching enables leaders to explore and think about alternative solutions to address issues.

Control of the agenda and the pace at which leaders felt comfortable sharing contributed to a willingness to explore a sensitive topic. Thinking could be tested, and the leader committed to trying new behaviours only when ready to do so:

'It allowed me to discover various insights at my own pace.' (P2) 'It gave me the opportunity to own the agenda and ways to reframe thinking and situations.' (P4)

Taking the time to delve deeply into the consequences of decisions and actions heightened the awareness of the importance of integrity. It seems that the likelihood of testing new behaviours and actions is increased when the decision rests with the leader. This observation is supported by the findings of Grant et al. (2010), Rekalde et al. (2015) and Sosik et al. (2012). McKergow (2016) stated that better decision-making is likely as a result of utilising an SF-CB approach.

\section{A focus on positive outcomes}

Recognition of existing strengths during coaching, and building on these, provided a base for increasing awareness of the importance of integrity:

'It felt that it was future-facing as opposed to focussing on the past.' (P1)

'In a way that is positive and not starting from scratch. I already know a lot.' (P6)

There was a sense that the coaching approach was energising, which supports willingness to experiment with change. Grant (2017a) explained that cognitive processing, such as identifying and activating resources and strengths, acts as a motivator to learn new behaviours.

The participants commented on recognising that they could find solutions to the integrity issues they were grappling with. This signals the resourcefulness of the participants: 
'This was a useful reminder that I have the capability to ... uhm ... mostly solve the questions myself, the coaching just helped me to remember.' (P2)

'The coaching helped me find other ways of tackling the issues.' (P5)

'Coaching assisted me in figuring out different ways of dealing with people.' (P6)

This claim of resourcefulness is confirmed by Linley, Woolston and Biswas-Diener (2009) who found that coaching supports the client in gaining a better understanding of existing strengths and in developing strengths more fully.

\section{Time as factor}

The participants highlighted that the duration of the coaching series was too short. One exception was P3 who commented that sometimes it is useful just to get a solution to the problem from the coach:

'Some days I am just looking for an answer to a question, and this coaching approach takes a bit of time.' (P3)

Business coaching is concerned with the development of managerial leaders and teams in a way that is sustainable, measurable and effective (Stout-Rostron, 2012). The sustainability of change, given the period of 5 weeks allocated to coaching in this study, is questionable. There would have been insufficient time to practise new behaviours (Grant, 2003). It is thus important to consider the appropriate number of sessions needed to facilitate permanent change.

In summary what emerged was the notion of a safe space created for the participants to explore challenges related to integrity and possible alternatives and solutions. There is no evidence that the safe space is a result of using an SF-CB approach specifically, but the likelihood of considering more alternatives and solutions through a strengths-based approach is supported by research (Grant et al., 2010). The participants believed that the coaching approach was energising and hence supported a willingness to change. This is in line with Grant's (2012) view that identifying resources and strengths acts as motivator for change.

\section{Positive leader outcomes as a result of coaching}

The participants reported on the contribution of coaching to leaders' awareness of the importance of integrity. Their accounts clustered around three superordinate themes: doing the right thing consistently, experimenting with change and impact of reflection.

\section{Doing the right thing consistently}

The participants referred to challenging someone in a position of power as being difficult. This is especially relevant when doing so in the presence of leaders who could have an impact on their career. There is an acknowledgement that it is important to do what is right and to do so consistently:
'It is about me having the courage to push back to senior leaders and then to see that it is possible to have the conversations.' (P2)

'I now think it is important to question or challenge, even if it makes me unpopular and impacts on my future.' (P3)

Palanski and Yammarino (2007) referred to consistency in difficult times, congruence between words and actions, and being truthful to oneself as actions to be practised by leaders to support integrity.

It seemed that acting with consistency drives team effectiveness and clarifies expectations:

'Then my team will know what to expect. And what I expect from them.' (P4)

'I mean if the team sees me acting with integrity it will have a lasting impression on them. A good impression.' (P6)

There is a realisation from the participants that integrity is not about self only, but also about the team and the positive impact on overall effectiveness and performance. Albert Bandura's social cognitive theory asserts that people learn through observation and leaders should model the behaviours they want to endorse in their teams (Seijts et al., 2017).

\section{Experimenting with change}

The participants reported a clear intent to behave differently in the future. Initial awareness spoke largely to understanding what integrity is, but not necessarily being willing to change own actions:

'I have not actually done this yet. But I want to speak up to make sure I am acting with integrity all the time.' (P1)

'I feel like I will speak up a little more than I currently do.' (P2)

It seems that awareness of the importance of integrity provides the momentum to act, but this is not the same as actually changing behaviour. The intent to change has to be followed through. Increasing awareness of the importance of certain behaviours could result in immediate change (Welch et al., 2014).

One participant explicitly noted the change in thinking as a result of coaching:

'After the coaching I realise that I was very inflexible in my thinking. In the beginning that is [pause] I was thinking more in the honesty space, which for me is all or nothing.' (P3)

Change in behaviour seemed to start with change in thinking, which is an indicator of readiness to start experimenting with change. This finding supports the view of Avolio and Gardner (2005) that reflecting on values, beliefs and feelings could change behaviour in the organisational context. It also supports the view of Grant (2017a) that cognitive processing such as facilitated reflections, which is central to SF-CB coaching, helps develop self-insight. 


\section{Impact of reflection}

Leading by example through self-checking and making adjustments where appropriate seems to be a result of reflection:

'I listen for it more and I ask myself more often if something I do or say is also about integrity.' (P2)

'And to reflect, continue to reflect on how I showed up in a specific situation. What else could I have done.' (P5)

Experiential learning theory describes how experience is transformed into learning through a cycle of knowledge acquisition involving experiencing, reflecting, thinking and acting (Kolb, 1984). It thus seems that coaching contributed to an increase in reflecting. As noted by Passmore (2007), reflection is especially important after coaching to integrate new behaviour.

The participants commented on leader reputation and the positive impact acting with integrity would have on teams:

'I am now questioning myself when I am withholding or not being fully transparent and authentic.' (P4)

'And I had to be vulnerable with the team.' (P5)

'I am more aware of the impression I create for people around me.' (P6)

The reputation of the leader appears to be based on the experience the team has with the individual and an effort by the leader to change behaviours will likely be perceived as positive. The focus shifts from the leader's self-interest to the attainment of common team goals, thus increasing effectiveness (MacKie, 2014).

Context was reported as important. The situation and the parties to the conversation were thought to have an impact on behaviour. Reality is acknowledged and participants spoke about the situations that could prevent them from speaking up:

'I was very worried about having a conversation with my leader about a deadline I am going to miss.' (P3)

'... like hiding your actions from others because you are scared. Scared that other people might not agree with you.' (P6)

It seems that coaching established a safe space for the leaders to reflect on how they showed up in various situations. Participants were optimistic about being able to recognise the context and still act with integrity. This is aligned with the view of Grant (2012) that coaching develops resilience in leaders to persevere regardless of context.

The main story that emerged from the final interviews exploring the contribution of coaching to leader awareness focussed on the importance of consistency in behaviour. It is consistency that allows leadership by example. This observation is supported by the views of Palanski and Yammarino (2007) and Seijts et al. (2017). An increase in participants' awareness could support the willingness to practise new behaviours. According to Welch et al. (2014), increased awareness could result in immediate change.
All participants commented on increased mindfulness and openness to engage with the topic of integrity to ensure sustainable change. This is in line with the view that sustained change is supported by strong relationships after coaching (Grant, 2017a; Welch et al., 2014).

\section{Conclusion}

Integrity as a dimension of character is relevant in the current South African organisational context. Leader integrity is imperative for effective leadership and sustainable performance.

This study identified the elements of coaching with a strengths-based approach, specifically an SF-CB approach, which suggests it to be an appropriate intervention for the development of awareness. The following coaching elements therefore support the development of leaders:

- Creating a safe space to explore the importance of awareness of integrity

- Recognising existing resources to build on future positive outcomes

- Prioritising the leaders' agenda to determine the length of the coaching series.

This research also highlighted that development in leader awareness could result in positive leader outcomes:

- Increased ability to act with consistency

- Willingness to experiment with new behaviours

- Self-checking to support immediate change.

This study contributes to the body of leadership and coaching literature on leaders' awareness of the importance of integrity and strengths-based coaching. The findings highlight the efficacy of using a strengths-based approach - specifically an SF-CB approach - in increasing leaders' awareness and driving positive leader outcomes.

The findings of this study have implications for organisations and coaches. The findings support the selection of coaching as a development intervention to achieve successful leader outcomes and could support human resources professionals deciding on an appropriate intervention for leader development. Furthermore, coaches could base their selection of approach on the evidence supporting the use of an SF-CB coaching approach in the context of developing leaders' awareness of the importance of integrity.

Further quantitative or qualitative research could confirm and enrich the findings and recommendations. Research about integrity is almost exclusively focussed at the individual level of analysis.

This study provided insights to guide coaches and human resources professionals on the effects of a coaching intervention with related positive outcomes for evidence on appropriate ways to enhance leaders' development in organisations. 


\section{Acknowledgements Competing interests}

The authors declare that they have no financial or personal relationships which may have inappropriately influenced them in writing this article.

\section{Authors' contributions}

L.v.d.W. conducted the research and wrote the article. S.v.C-P. supervised the project and edited the final draft.

\section{Ethical consideration}

This research received clearance from the University of Stellenbosch Business School's Ethics Committee. All participants signed informed consent documents in which they were made aware of their rights as research participants (clearance number: USB-2019-9915).

\section{Funding information}

This research received no specific grant from any funding agency in the public, commercial or not-for-profit sectors.

\section{Data availability statement}

Data sharing is not applicable to this article as no new data were created or analysed in this study.

\section{Disclaimer}

The views and opinions expressed in this article are those of the authors and do not necessarily reflect the official policy or position of any affiliated agency of the authors.

\section{References}

Avolio, B.J., \& Gardner, W.L. (2005). Authentic leadership development: Getting to the root of positive forms of leadership. Leadership Quarterly, 16(3), 315-338. https://doi.org/10.1016/j.leaqua.2005.03.001

Anthony, E.L. (2017). The impact of leadership coaching on leadership behaviors Journal of Management Development, 36(7), 930-939. https://doi.org/10.1108/ JMD-06-2016-0092

Babbie, E., \& Mouton, J. (2012). The practice of social research. Cape Town: Oxford University Press.

Bannink, F., \& Jackson, P.Z. (2011). Positive psychology and solution focus: Looking at similarities and differences. InterAction, 3(1), 8-20. Retrieved from https://www. researchgate.net/publication/233631755_Positive_Psychology_and_Solution_ Focus_-_looking_at_similarities_and_differences

Bass, B.M. (1985). Leadership and performance beyond expectations. New York, NY: The Free Press.

Bass, B.M., \& Steidlmeier, P. (1999). Ethics, character, and authentic transformational leadership behavior. The Leadership Quarterly, 10(2), 181-217. https://doi. org/10.1016/S1048-9843(99)00016-8

Bauman, D.C. (2013). Leadership and the three faces of integrity. The Leadership Quarterly, 24(3), 414-426. https://doi.org/10.1016/j.leaqua.2013.01.005

Becker, G.K. (2009). Integrity as moral ideal and business benchmark. Journal of International Business Ethics, 2(2), 70-88. Retrieved from https://pdfs. semanticscholar.org/14b0/ace8736363e0be11c76953cc9c3516650ca2.pdf

Bloomberg, L.D., \& Volpe, M. (2008). Completing your qualitative dissertation: A roadmap from beginning to end. Los Angeles, CA: Sage.

Braun, V., \& Clarke, V. (2013). Successful qualitative research: A practical guide for beginners. London: Sage.

Cohen, T.R., Panter, A.T., Turan, N., Morse, L., \& Kim, Y. (2014). Moral character in the workplace. Journal of Personality and Social Psychology, 107(5), 943-963. https:// doi.org/10.1037/a0037245
Conger, J., \& Hollenbeck, G.P. (2010). What is the character of research on leadership character? Consulting Psychology Journal: Practice and Research, 62(4), 311-316. https://doi.org/10.1037/a0022358

Cox, E., Bachkirova, T., \& Clutterbuck, D. (2014). Theoretical traditions and coaching genres. Advances in Developing Human Resources, 16(2), 139-160. https://doi. org/10.1177/1523422313520194

Crossan, M.M., Byrne, A., Seijts, G.H., Reno, M., Monzani, L., \& Gandz, J. (2017). Toward a framework of leader character in organizations. Journal of Management Studies, 54(7), 986-1018. https://doi.org/10.1111/joms.12254

De Haan, E., Culpin, V., \& Curd, J. (2011). Executive coaching in practice: What determines helpfulness for clients of coaching? Personnel Review, 40(1), 24-44. https://doi.org/10.1108/00483481111095500

Ely, K., Boyce, L.A., Nelson, J.K., Zaccaro, S.J., Hernez-Broome, G., \& Whyman, W. (2010). Evaluating leadership coaching: A review and integrated framework. The Leadership Quarterly, 21(4), 585-599. https://doi.org/10.1016/j. leaqua.2010.06.003

Fredrickson, B.L. (2001). The role of positive emotions in positive psychology. American Psychologist, 56(3), 218-226. https://doi.org/10.1037/0003-066X.56.3.218

Gentry, W.A., Cullen, K.L., Sosik, J.J., Chun, J.U., Leupold, C.R., \& Tonidandel, S. (2013). Integrity's place among the character strengths of middle-level managers and
top-level executives. The Leadership Quarterly, 24(3), 395-404. https://doi. top-level executives. The Leadership
org/10.1016/j.leaqua.2012.11.009

Glass, C. (2009). Exploring what works: Is SF the best way of harnessing the impact of positive psychology in the workplace? InterAction, 1(1), 26-41. Retrieved from http://ez.sun.ac.za/login?url=https://search-proquest-com.ez.sun.ac.za/docview http://ez.sun.ac.za/login?url=https:
/1029929756?accountid $=14049$

Grahek, M.S., Thompson, A.D., \& Toliver, A. (2010). The character to lead: A closer look at character in leadership. Consulting Psychology Journal: Practice and Research, 62(4), 270-290. https://doi.org/10.1037/a0022385

Grant, A.M. (2003). The impact of life coaching on goal attainment, metacognition and mental health. Social Behavior and Personality: An International Journal, 31(3), 253-263. https://doi.org/10.2224/sbp.2003.31.3.253

Grant, A.M. (2012). An integrated model of goal-focused coaching: An evidence-based framework for teaching and practice. International Coaching Psychology Review, 7(2), 146-165. https://doi.org/10.1080/17521880903102308

Grant, A.M. (2014). The efficacy of executive coaching in times of organisational change. Journal of Change Management, 14(2), 258-280. https://doi.org/10.10 80/14697017.2013.805159

Grant, A.M. (2017a). Solution-focused cognitive-behavioral coaching for sustainable high performance and circumventing stress, fatigue, and burnout. Consulting Psychology Journal, 69(2), 98-111. https://doi.org/10.1037/cpb0000086

Grant, A.M. (2017b). The third 'generation' of workplace coaching: Creating a culture of quality conversations. Coaching: An International Journal of Theory, Research and Practice, 10(1), 37-53. https://doi.org/10.1080/17521882.2016.1266005

Grant, A.M., Green, L.S., \& Rynsaardt, J. (2010). Developmental coaching for high school teachers: Executive coaching goes to school. Consulting Psychology Journal: Practice and Research, 62(3), 151-168. https://doi.org/10.1037/a0019212

Grover, S., \& Furnham, A. (2016). Coaching as a developmental intervention in organisations: A systematic review of its effectiveness and the mechanisms underlying it. PLoS One, 11(7), 1-41. https://doi.org/10.1371/journal. pone.0159137

Hannah, S.T., \& Avolio, B.J. (2011). The locus of leader character. The Leadership Quarterly, 22(5), 979-983. https://doi.org/10.1016/j.leaqua.2011.07.016

Hannah, S.T., \& Jennings, P.L. (2013). Leader ethos and big-c character. Organizational Dynamics, 42(1), 8-16. https://doi.org/10.1016/j.orgdyn.2012.12.002

Jones, R.J., Woods, S.A., \& Guillaume, Y.R.F. (2016). The effectiveness of workplace coaching: A meta-analysis of learning and performance outcomes from coaching. Journal of Occupational and Organizational Psychology, 89(2), 249-277. https:// doi.org/10.1111/joop.12119

Kahn, M.S. (2011). Coaching on the axis: An integrative and systemic approach to business coaching. International Coaching Psychology Review, 6(2), 194-210. Retrieved from https://www.researchgate.net/publication/277291010_Kahn_ MS_2011_Coaching_on_the_Axis_An_integrative_and_systemic_approach_to_ business_coaching_International_Coaching_Psychology_Review_62_194210

Kaiser, R.B., \& Hogan, R. (2010). How to (and how not to) assess the integrity of managers. Consulting Psychology Journal: Practice and Research, 62(4), 216-234. https://doi.org/10.1037/a0022265

Kegan, R. (1982). The evolving self: Problem and process in human development. Cambridge, MA: Harvard University Press.

Kolb, D.A. (1984). Experiential learning: experience as the source of learning and development. Englewood Cliffs, NJ: Prentice Hall.

Linley, P.A., Woolston, L., \& Biswas-Diener, R. (2009). Strengths coaching with leaders International Coaching Psychology Review, 4(1), 37-48. Retrieved from https:// psycnet.apa.org/record/2009-05739-005

Macintyre, A. (2007). After virtue: A study in moral theory (3rd edn.). New York, NY: Bristol Classical Press.

Mackie, D. (2014). The effectiveness of strength-based executive coaching in enhancing full range leadership development: A controlled study. Consulting Psychology Journal: Practice and Research, 66(2), 118-137. https://doi. org/10.1037/cpb0000005

McKenna, R.B., \& Campbell, G.V. (2011). The character $x$ factor in selecting leaders: Beyond ethics, virtues, and values. Journal of Values Based Leadership, 4(5),
39-48. Retrieved from http://www.valuesbasedleadershipjournal.com/issues/ vol4issue2/selecting_leaders.php 
McKergow, M. (2016). Better decision making with solution focused coaching. InterAction, 8(2), 7-19.

Mclaughlin, M. (2013). Coaching for brave leadership: An action research study. International Journal of Evidence Based Coaching and Mentoring, June(S7), 125-139. Retrieved from https://radar.brookes.ac.uk/radar/items/4e4ab51e-2b61-43028301-c1aa8bc116b6/1/

Naudé, P., Hamilton, B., Ungerer, M., Malan, D., \& De Klerk, M. (2018). Business perspectives on the Steinhoff saga. USB Management Review, June 2018, 1-36. Retrieved from https://www.researchgate net/publication/337740231 BUSINESS_PERSPECTIVES_ON_THE_STEINHOFF_SAGA_SPECIAL_REPORT_ JUNE_2018

Newstead, T., Dawkins, S., Macklin, R., \& Martin, A. (2019). The virtues project: An approach to developing good leaders. Journal of Business Ethics, April, 1-18. https://doi.org/10.1007/s10551-019-04163-2

Palanski, M.E., \& Yammarino, F.J. (2007). Integrity and leadership: Clearing the conceptual confusion. European Management Journal, 25(3), 171-184. https:// doi.org/10.1016/j.emj.2007.04.006

Palanski, M.E., \& Yammarino, F.J. (2011). Impact of behavioral integrity on follower job performance: A three-study examination. The Leadership Quarterly, 22(4), 765-786. https://doi.org/10.1016/j.leaqua.2011.05.014

Passmore, J. (2007). An integrative model for executive coaching. Consulting Psychology Journal: Practice and Research, 59(1), 68-78. https://doi. org/10.1037/1065-9293.59.1.68

Peterson, C., \& Seligman, M.E.P. (2004). Character strengths and virtues. A handbook and classification. New York, NY: Oxford.

Rekalde, I., Landeta, J., \& Albizu, E. (2015). Determining factors in the effectiveness of executive coaching as a management development tool. Management Decision 53(8), 1677-1697. https://doi.org/10.1108/MD-12-2014-0666

Riggio, R.E. (2008). Leadership development: The current state and future expectiations. Consulting Psychology Journal: Practice and Research, 60(4), 383-392. https://doi. org/10.1037/1065-9293.60.4.383

Ryan, R.M., \& Deci, E.L. (2000). Self-determination theory and the facilitation of intrinsic motivation, social development, and well-being. American Psychologist, 55(1), 68-78. https://doi.org.ez.sun.ac.za/10.1037/0003-066X.55.1.68

Seijts, G., Crossan, M., \& Carleton, E. (2017). Embedding leader character into HR practices to achieve sustained excellence. Organizational Dynamics, 46(1), 30-39. https://doi.org/10.1016/j.orgdyn.2017.02.001

Seijts, G., Gandz, J., Crossan, M., \& Reno, M. (2015). Character matters: Character dimensions' impact on leader performance and outcomes. Organizational Dynamics, 44(1), 65-74. https://doi.org/10.1016/j.orgdyn.2014.11.008
Seijts, G.H., \& Gandz, J. (2018). Transformational change and leader character Business Horizons, 61(1), 239-249. https://doi.org/10.1016/j.bushor.2017.11.005

Seligman, M.E.P., \& Csikszentmihalyi, M. (2000). Positive psychology: An introduction American Psychologist, 55(1), 5-14. https://doi.org/10.1037//0003-066x.55.1.5

Six, F.E., De Bakker, F.G.A., \& Huberts, L.W.J.C. (2007). Judging a corporate leader's integrity: The perceived alignment between managers' words and deeds as a research focus. European Management Journal, 25(3), 185-194. https://doi. org/10.1016/j.emj.2007.04.003

Smith, J.A., Flowers, P., \& Larkin, M. (2009). Interpretative phenomenological analysis: Theory, method and research. London: Sage.

Smith, J.A. (2011). Evaluating the contribution of interpretative phenomenological analysis. Health Psychology Review, 5(1), 9-27. https://doi.org/10.1080/174371 99.2010.510659

Sosik, J.J., \& Cameron, J.C. (2010). Character and authentic transformational leadership behavior: Expanding the ascetic self toward others. Consulting Psychology Journal: Practice and Research, 62(4), 251-269. https://doi.org/10.1037/a0022104

Sosik, J.J., Gentry, W.A., \& Chun, J.U. (2012). The value of virtue in the upper echelons: A multisource examination of executive character strengths and performance. The Leadership Quarterly, 23(3), 367-382. https://doi.org/10.1016/j. leaqua.2011.08.010

Stout-Rostron, S. (2012). Business coaching: Wisdom and practice: Unlocking the secrets of business coaching (2nd edn.). Randburg: Knowres Publishing.

Theeboom, T., Beersma, B., \& Van Vianen, A.E.M. (2014). Does coaching work? A meta-analysis on the effects of coaching on individual level outcomes in an organizational context. The Journal of Positive Psychology, 9(1), 1-18. https://doi. org/10.1080/17439760.2013.837499

Visser, C. (2009). Brief descriptions and reflections on recent research articles and books relevant to the development of SF practice and theory. InterAction, 1(2), 131-135. Retrieved from http://ez.sun.ac.za/login?url=https://search-proquestcom.ez.sun.ac.za/docview/1029935960?accountid $=14049$

Welch, D, Grossaint, K Reid, K \& Walker, C. (2014). Strengths-based leadership development: Insights from expert coaches. Consulting Psychology Journal: Practice and Research, 66(1), 20-37. https://doi.org/10.1037/cpb0000002

Willig, C. (2008). Introducing qualitative research in psychology (2nd edn.). Milton Keynes: Open University Press.

Wright, T.A., \& Quick, J.C. (2011). The role of character in ethical leadership research. The Leadership Quarterly, 22(5), 975-978. https://doi.org/10.1016/j. leaqua.2011.07.015 